\title{
Human papillomaviruses and non-melanoma skin cancer: Basic virology and clinical manifestations
}

\author{
Ingo Nindl*, Marc Gottschling and Eggert Stockfleth \\ Department of Dermatology, Charité, Skin Cancer Center Charité, University Hospital of Berlin, Charitéplatz 1, \\ D-10117 Berlin, Germany
}

\begin{abstract}
Human papillomaviruses (HPV) infect cutaneous and mucosal epithelia and induce benign and malignant lesions. Non-melanoma skin cancer (NMSC), encompassing basal cell carcinoma and squamous cell carcinoma (SCC), is the most frequent cancer in the Caucasian population, and the incidence has increased dramatically worldwide. Ultraviolet (UV) radiation is a major risk factor for NMSC, and cutaneous HPV is also considered to play an active role during the pathogenesis of these cancers. The first evidence for the involvement of HPV in NMSC was reported in patients with Epidermodysplasia verruciformis (EV). HPV types detected in skin tumours of these patients are referred to as EV/cutaneous HPV types belonging to the betaand gamma-papillomaviruses (PV). Epidemiological studies have shown a higher risk of several EV/cutaneous HPV types for NMSC. Furthermore, in vitro and animal models show transforming properties of some PV types. The anti-apoptotic activities, and the delay of DNA repair mechanism caused by some EV/cutaneous HPV E6 proteins in response to UV-induced mutations, may lead to the persistence of DNA-damaged keratinocytes. Thus, specific EV/cutaneous HPV types as co-factors in association with UV-radiation and the immune system seem to be involved in the early pathogenesis of cutaneous SCC.
\end{abstract}

Abbreviations: AK, actinic keratosis; EV, Epidermodysplasia verruciformis; HPV, human papillomavirus; LOH, loss of heterozygosity; NMSC, non-melanoma skin cancer; PV, papillomavirus; SCC, squamous cell carcinoma; OTR, organ transplant recipient; UV, Ultraviolet.

\section{NMSC and ultraviolet radiation}

Non-melanoma skin cancer (NMSC), comprising basal cell carcinoma (BCC), Bowen's disease, cutaneous squamous cell carcinoma (SCC), and its early stage actinic keratosis (AK), is the most frequent malignancy among populations of European origin [15]. The tumours are readily diagnosed on the basis of clinical and histopathological appearance (Fig. 1AC). BCC rarely metastasises and shows ingrowths of epidermal keratinocytes adjacent to palisades of cells resembling those that constitute the lower basal layer [6,7]. They frequently occur on the face and are

*Corresponding author: I. Nindl, PhD. Tel.: +49 30450518 269; Fax: +4930450 518 969; E-mail: ingo.nindl@charite.de. characteristically indolent, small, pearly edged lesions with sometimes an ulcerated centre. On the contrary, SCC are invasive tumours, whose cells histologically appear like differentiated suprabasal keratinocytes, and approximately $3 \%$ metastasises [7]. They grow faster than BCC and produce a more indurated, hyperkeratotic lesion with ulceration. AK and cutaneous SCC frequently occur as multiple primary tumours in the same skin area ('field') in proximity to each other ('field cancerisation'; Fig. 1) [8].

During the last decade, worldwide incidence of NMSC has epidemically increased and now represents approximately $30 \%$ of total cancers [9-12]. Particularly, light-skinned and sun-sensitive individuals are affected, and the highest frequencies of the disease are found on sun-exposed sites of the body (Fig. 1G-J) [13]. Furthermore, skin cancer risk is relatively increased in 

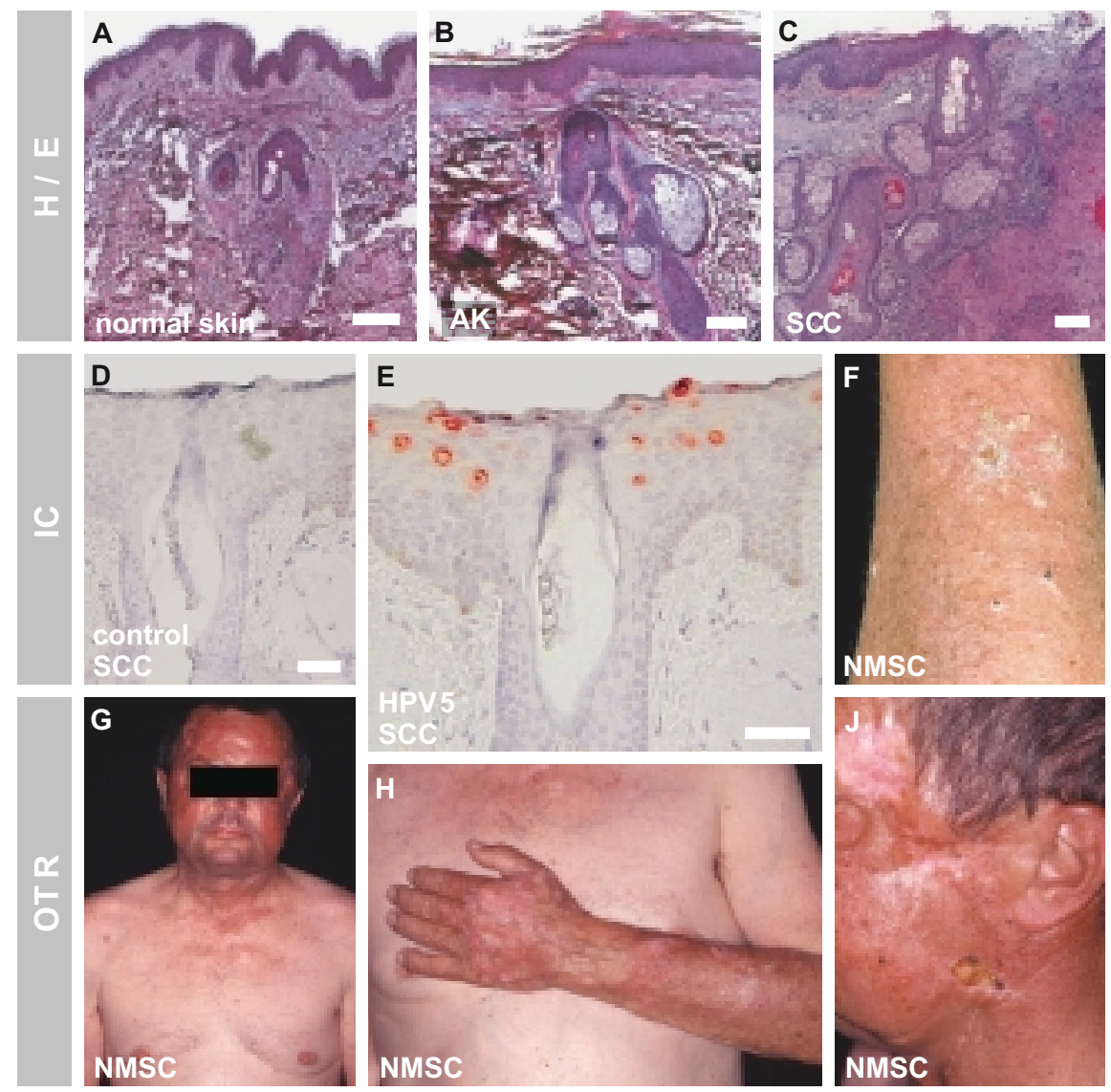

Fig. 1. Non-melanoma skin cancer (NMSC) from an immunocompetent (IC) patient and an immunosuppressed organ transplant recipient (OTR). Sections of paraffin embedded skin tissues stained with haematoxylin and eosin (H / E) for histology (A-C). Normal skin (A), actinic keratosis (AK) (B), and cutaneous squamous cell carcinoma (SCC) (C). Presence of beta-human papillomavirus (HPV) DNA in dysplastic cells of cutaneous SCC (IC patient, 86 years old female) shown by in situ hybridisation (ISH) (A. Köhler and I. Nindl, unpublished data) (D,E). Negative control using the HPV 16 genome (D), tyramide signal amplification after ISH, red staining indicate HPV 5 DNA in the nucleus. HPV 5 DNA was not detected in all dysplastic cells, and note the enlarged nuclei in the HPV positive dysplastic cells (E). Field cancerisation with multiple AK and SCC is shown on the forearm of an IC patient (F). Development of multiple AK and SCC exclusively on sun-exposed areas as demonstrated with an immunosuppressed OTR (G-J). Head and chest $(\mathrm{G})$, trunk and left $\operatorname{arm}(\mathrm{H})$, left lateral face $(\mathrm{J})$. Originals, magnification scale bars indicate $50 \mu \mathrm{m}$.

Caucasians who have been born in countries close to the equator, compared to those who have migrated to them after birth, indicating that the exposure to solar radiation early in life has importance for tumourgenesis [14]. This highlights the role of ultraviolet- (UV) rays as a major environmental risk factor for the development of epithelial skin cancers [15-18]. The major physical adaptation to UV-radiation, which is the most ubiquitous human carcinogen, is pigmentation of the skin, whose degree is largely based on inheritance.

UV-radiation is a component of sunlight and comprises three wavelength classes, UV-C (ranging from 190 to $280 \mathrm{~nm})$, UV-B (280 to $320 \mathrm{~nm})$, and UV-A (320 to $400 \mathrm{~nm}$ ). The non-ionising radiation cumulatively induces NMSC by at least two interacting rather than separate mechanisms, causing permanent DNA damage and preventing local immunologic recognition of mutant cells [19]. UV-A induces photooxidative stress and secondarily characteristic genome mutations, while UV-B irradiation results directly in the formation of cyclobutane (thymidine) dimers and transitions in DNA. Because of the absence of effective repair mechanisms, such genetic changes lead to permanent mutations in keratinocytes, which subsequently have the potential to progress into epithelial skin cancer $[15,18,20,21]$.

The development of BCC shows a different etiology compared to SCC and is rather marginally subjected to the immune system. It is considered a hair folliclederived tumour [22] resulting from relatively few genetic alterations that are largely well understood [17]. 
More than $70 \%$ of hereditary and non-hereditary BCC carry a loss of heterozygosity $(\mathrm{LOH})$ at $9 \mathrm{q}$, and loss of 9q22-31 is associated with the Gorlin's syndrome (nevoid BCC syndrome) [23]. In turn, patients suffering from that syndrome exhibit a high risk to develop BCC during the entire lifetime, but are frequently affected by the presence of multiple BCC already at early age $[24,25]$. The autosomal dominant disorder is based on a germline mutation and persistent inactivation of the tumour suppressor gene PTCH1 located at chromosome $9 q$ [26-28] that is involved in the sonic hedgehog (SHH) signalling pathway resulting in activation of the transcription factor Glil.

Despite increasing knowledge of BCC development, little is known about the causal alterations of cutaneous SCC. However, the development of SCC clearly results from the mutual interaction of multiple factors that is reflected by, for example, distinct $\mathrm{LOH}$ patterns of both various chromosomes and many genes in this disease [29]. LOH has been specifically identified on chromosome 3 (25\%), 9 (40\%), and 17 (40\%), with an overall fractional allelic loss of $30 \%$ [30,31]. Recently, 118 differentially expressed genes have been identified by the expression profile of 22,283 genes in normal human skin biopsies compared with $\mathrm{AK}$ and cutaneous SCC [32]. Cutaneous SCC is not associated with any hereditary disease, but aneuploidy is frequent occurring in between 20 to $80 \%$ of patients [33,34]. UV-B fingerprint type of mutations in NMSC, comprising characteristic $\mathrm{C} \rightarrow \mathrm{T}$ and $\mathrm{CC} \rightarrow \mathrm{TT}$ substitutions, have been particularly identified in the target genes $p 53$ (chromosome 17p13.1) [35,36], p16 ${ }^{\text {INK4a }}$ (chromosome 9p21) [3740], and Ha-ras (chromosome 11p15.5) [17,41,42]. p53-mutant cells fail to undergo apoptosis because of UV-induced cellular injury and might also have a selective growth advantage to repopulate injured areas after sunburn events $[36,43]$. Thus, genomic instability is a driving force in skin cancer development in general, but p53 mutations rather than $p 16^{\text {INK4a }}$ and/or Ha-ras mutations seem to be early events during the development of SCC (Nindl et al., unpublished data) [17].

The number of NMSC is remarkably increased in organ transplant recipients (OTR) underscoring the correlation between skin cancer and immune status [44]. Cumulatively, the main risk factors for cutaneous SCC are long-term exposure to UV-radiation, fairly pigmented skin, and immune status. Furthermore, several studies reveal a role of human papillomaviruses (HPV) in the multi-step process of skin carcinogenesis as a co-factor with UV-radiation [45].

\section{Human Papillomaviruses}

Papillomaviruses (PV) are small DNA viruses with a genome of nearly 8,000 base pairs. They are host specific and have been found in more than 20 different mammalian and avian species. HPV infect keratinocytes of skin and mucosa (Fig. 1D-E), and their lifecycle is adapted to the differentiation of the host cells [46]. Presently, about 100 HPV types have been completely sequenced and are classified into mucosal/genital and cutaneous types based on sequence analyses and clinical manifestation. Phylogenetic analysis of complete L1 gene sequences identify a series of taxonomic units such as alpha-, beta-, and gammaPV [47]. The human mucosal/genital types belong to the alpha-PV and can be divided into low-risk and high-risk types as inferred from their association with benign and malignant cervical lesions [48-50]. Lowrisk types such as HPV 6 and HPV 11 have the potential to induce genital warts (Condylomata acuminata), whereas high-risk types such as HPV 16 and HPV 18 are causally involved in carcinogenesis of the uterine cervix and other mucosae of anogenital and oropharyngeal sites [49,51]. Cutaneous HPV are phylogenetically heterogeneous, and the classical cutaneous wartsassociated types (species 2 and 4 of alpha-PV, mu-, and nu-PV) can be distinguished from the Epidermodysplasia verruciformis (EV)-associated or EV/cutaneous types (beta- and gamma-PV) [47,52].

The E5 proteins are considered to access oncogenic potential and are specifically present in alpha- and delta-PV but are absent in EV/cutaneous types. The alpha-PV E5 proteins are classified into four groups based on the clinical manifestations of the corresponding viral infection: the presence of E5-alpha that is found in high-risk types correlates with cervical cancer, E5-gamma and/or E5-delta are associated with mucosal benign lesions, and E5-beta corresponds to benign cutaneous lesions [53,54]. Recent studies reveal a pathogenic role of EV/cutaneous HPV types in the development of NMSC (Fig. 2). In order to prove the causal involvement of HPV in the development of malignancies, specific criteria have to be fulfilled such as the presence and activity of the virus in cells of human skin cancer lesions and evidence on transforming properties of viral genes.

\section{HPV and NMSC}

\subsection{Epidermodysplasia verruciformis}

The rare heritable disorder EV was initially described in 1922 by the Swiss physician Felix Lewandowsky 


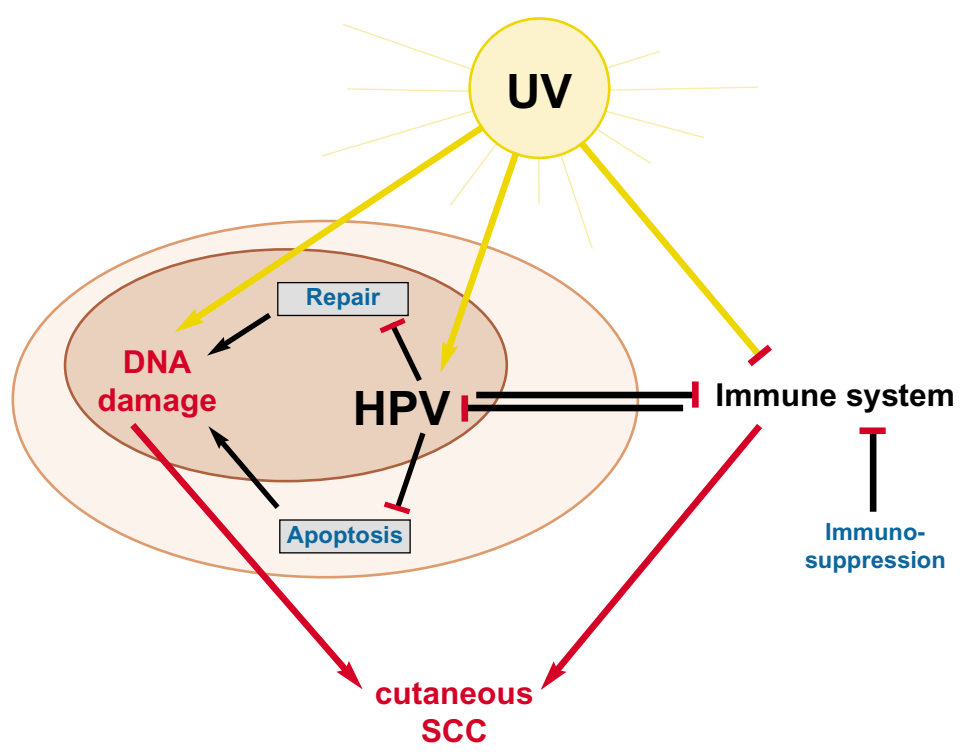

Fig. 2. Multiple risk factors during skin carcinogenesis. Important risk factors for cutaneous squamous cell carcinoma (SCC) are (i) UV-radiation, (ii) EV/cutaneous HPV, and (iii) the immune status. UV-radiation increases the expression of viral genes, induces DNA-damage in keratinocytes, and locally causes immunosuppression. The anti-apoptotic activities, and the delay of DNA repair mechanisms, influenced by HPV in response to UV-induced mutations may lead to the persistence of DNA-damaged keratinocytes and subsequently to skin cancer. Additionally, a low immune status is associated with an increased risk for the development of cutaneous SCC.

under the assistance of Wilhelm Lutz [55]. The disease exhibits extensive polymorphous warts mainly located on sun-exposed sites, which proceed into cutaneous SCC in about $30 \%$ of the patients [56,57]. The first evidence for the involvement of HPV in skin cancer was reported from EV patients. The EV types HPV 5 and HPV 8 have been detected in $90 \%$ of cutaneous SCC in these patients, whereas HPV 14, HPV 17, HPV 20, and HPV 47 are rarely found in this carcinoma [58].

The genome of EV/cutaneous HPV types is mostly not integrated into the host genome and persists extrachromosomally [59]. This is in contrast to cervical cancer-associated high-risk alpha-HPV, whose viral genome is usually integrated into the host chromosome(s) [60]. HPV DNA persist in high copy numbers in cutaneous SCC (100-300 viral copies per cell equivalent), but not all cancerous cells are HPV-infected [61]. EV/cutaneous HPV types are transcriptionally active in both AK and cutaneous SCC [62,63]. Moreover, persistent HPV infections in cutaneous primary and metastasised SCC from EV patients have been reported $[64,65]$, which may result from a defect of the innate or adaptive immune system by a still unknown mechanism [66].

The eight vertebrate transmembrane cochlear (TMC) expressed genes are evolutionary conserved and encode proteins that constitute three subfamilies. The proteins comprise at least eight membrane-spanning domains, and are located in the endoplasmatic reticulum [67]. The first susceptibility gene locus associated with EV (i.e., EV1) is mapped to chromosome 17q25 [68] and the second locus (EV2) to chromosome 2p21-p24 [69]. Two homologous genes, TMC6 (EVERI) and TMC8 (EVER2), have been identified at the EV1 locus, and nonsense mutations of these genes increase the susceptibility to infection with particular beta-HPV types resulting in a higher risk for cutaneous SCC [70,71]. They appear to be involved in the regulation of the immune system, and additionally in the replication of $\mathrm{EV} /$ cutaneous HPV, but the precise function has still to be determined. Moreover, antibodies against betaHPV types have been found at young ages from EV patients, but age-matched sera from the general population are usually HPV-seronegative (M. Pawlita, personal communication) indicating that viral replication is perturbed in EV patients. Future studies are highly desirable, since knowledge about the mechanism will provide further insights in how EV/cutaneous HPV are controlled at the cellular level and how weak control may contribute to the increased risk for skin cancer.

\subsection{General population}

Among children from 1 month to 4 years, the prevalence of cutaneous HPV DNA in forehead swabs vary 
between 50 to $70 \%$ [72]. Asymptomatic cutaneous HPV infections of normal skin thus occur very early in infancy caused by a high multiplicity of HPV. Boxman and colleagues [73] firstly detected EV/cutaneous HPV types in hair follicles from eyebrows, arms, and/or legs in 10 of 22 healthy volunteers (45\%). Furthermore, cutaneous HPV types have been found in plucked eyebrow hairs in up to $67 \%$ of immunocompetent individuals [73-75] and hair follicles are probably a reservoir of EV/cutaneous types. An individual spectrum of EV/cutaneous HPV types is present in plucked hairs from immunocompetent individuals, and similar types are found in different skin areas from both sun-exposed and non sun-exposed sites [76]. Possibly, the skin of each human is infected with an individual pattern of cutaneous HPV types, whose replication is controlled by the immune system. Genital alpha-HPV has been rarely detected in skin samples indicating the high specificity of HPV types to the host tissue.

Over the last two decades, several PCR methods using degenerate, nested and/or type-specific primers followed by sequencing, hybridisation, or cloning and sequencing have been developed to detect a broad range of cutaneous HPV types [73,77-81]. Different prevalence rates of EV/cutaneous HPV types have been reported in NMSC from immunocompetent patients, most likely due to the differences in the detection system used. This assumption has been confirmed by studies reporting increased prevalence rates when a combination of different primer sets have been applied [82, 83]. Recently, two high-throughput PCR-based HPV detection systems have been developed in order to identify EV/cutaneous HPV types with a high sensitivity and both systems are applicable for future large epidemiological studies [84,85].

Overall, the number of EV/cutaneous HPV types in NMSC is higher (27 to $85 \%$ ) compared to normal skin (15 to 35\%) [86-92]. The highest prevalence rate of EV/cutaneous HPV types have been detected in 97 of 114 immunocompetent AK patients (85\%) [90]. Moreover, the virus load in skin tumours is low, and a single HPV copy can be detected in only 10 to 1,000 dysplastic cells $[88,93,94]$. The highest virus load of 6 EV/cutaneous HPV types examined was found in 20 AK, followed by 6 SCC, and has been least in 1 metastasis [95]. Thus, the virus load of EV/cutaneous HPV in cutaneous SCC is very low, and the number of HPV infected cells may decrease during skin carcinogenesis.

An increased risk of SCC, but not BCC, has been associated with EV/cutaneous HPV types in two epidemiological studies investigating viral DNA in eye- brow hairs $[75,96]$. EV/cutaneous HPV types were detected in hairs from 17 of $25 \mathrm{SCC}(68 \%)$ versus 14 of 25 controls $(56 \%)$ resulting in a non-significant positive association of HPV with SCC (odds ratio 2.00, 95\% confidence interval 0.50-8.0) [75]. In another casecontrol study, a positive association of EV/cutaneous HPV and SCC was found (odds ratio 1.7, 95\% confidence interval 1.1-2.7), with prevalence rates of $75 \%$ in SCC (116 of 155) versus 58\% in controls (216 of 371) [96]. However, an association of a specific HPV type with SCC has not been determined to date. In a few, small epidemiological studies investigating seroreactivity of EV/cutaneous HPV an increased risk of HPV 8 and SCC has been reported [97-99]. A larger study has examined antibody response to six EV/cutaneous types (i.e., HPV types 5, 8, 15, 20, 24, and 38) in 161 SCC, 454 BCC, and 386 control patients [100]. Seroreactivity of HPV 8 and HPV 38 was significantly increased in SCC versus controls. In a recent large epidemiological case-control study, antibodies against 16 HPV types (HPV 1, 2, 3, 5, 6, 8, 9, 10, 15, 16, $20,24,32,36,38$, and 57) belonging to beta-, alpha-, and mu-PV have been investigated in 252 SCC, 525 $\mathrm{BCC}$, and 461 control patients using a newly developed multiplex serology [101]. An increased risk of betaHPV, particularly HPV 5 (odds ratio 1.8, 95\% confidence interval 1.0 to 3.1) and SCC, but no association of HPV seropositivity and BCC was found. In conclusion, clinical and epidemiological data support a role of EV/cutaneous HPV in the development of SCC and not BCC.

\subsection{Immunosuppressed organ transplant recipients}

Persistent HPV-induced warts, AK, and cutaneous SCC, which mainly arise on sun-exposed sites, are the main types of cutaneous tumours in immunosuppressed OTR $[4,102,103]$. Within 15 years after transplantation, up to $40 \%$ of renal transplant recipients have developed NMSC [104]. These cancers predominately represent SCC, but only to a lesser extent BCC. Compared to the general population, the incidence of cutaneous SCC and BCC is approximately 150 -fold and 10fold higher in transplant recipients, respectively, thus leading to a reversal of the SCC to BCC ratio of 1:4 in the general population to $5: 1$ in transplant recipients $[16,44,105,106]$. Cutaneous SCC in OTR shows characteristic clinical and morphological features with HPV-induced warts [107]. An important observation is the association and co-localisation of cutaneous SCC with HPV-induced warts in OTR indicating that per- 
sistent warts may be progress into skin cancer [108]. Overall, the EV/cutaneous HPV prevalence rate, and the number of multiple types, was higher in cutaneous SCC from immunosuppressed OTR in comparison to the general population. Moreover, OTR have a higher HPV prevalence rate of up to $90 \%$ in cutaneous SCC compared to normal skin (11 to $32 \%$ ) [79,87, $88,92,109-113]$. In up to $92 \%$ of plucked eyebrow hairs, EV/cutaneous HPV types have been detected [73, 74] leading to low differences in comparison to HPV prevalence of patients with cutaneous SCC. A large European epidemiological study examined the risk of EV/cutaneous HPV types for SCC in 219 OTR with and 550 without a history of cutaneous SCC. An increased risk of one or more EV/cutaneous HPV types in eyebrow hairs for cutaneous SCC have been found in OTR (odds ratio 3.00, 95\% confidence interval 1.5-6.2) (J.N. Bouwes Bavinck and the EPI-HPV-UV-CA group, abstract, $4^{\text {th }}$ HPV and Cancer Meeting, November 2006, Turin, Italy). Moreover, a higher prevalence of seroreactivity against beta-HPV was found in OTR with SCC $(60 \%)$ versus in OTR without SCC (55\%). Persistent EV/cutaneous HPV infection with the same variant in primary skin SCC, recurrence, and metastases in organ transplant recipients has been reported [94]. Two studies report viral activity of EV/cutaneous HPV types in cutaneous SCC [114,115]. E2 and E4 transcripts have been detected in $20 \%$ of warts and $38 \%$ of SCC, and E6/E7 transcripts have been found in a single SCC only [114]. Transcriptional activity of the EV/cutaneous HPV types 8, 9, and 15 of E6/E7 has been detected in 4 of 10 viral positive $\mathrm{AK}$ and cutaneous SCC from immunosuppressed OTR [115]. Thus, viral activity of early genes seems to be present in at least a subset of AK and cutaneous SCC suggesting a role for HPV during skin carcinogenesis.

\section{Molecular mechanisms and transforming properties of EV/cutaneous HPV}

\subsection{In vitro models}

\subsubsection{Monolayer}

Using monolayer cultures, the E6 gene of HPV 8 shows transforming properties in rodent fibroblast lines (C127, Rat 1), whereas HPV $8 \mathrm{E} 7$ is involved in the replication of the viral DNA [116]. HPV 47 E6 is required and sufficient for the transformation of the rat fibroblastic cell line (3Y1) [117]. The E6 genes of the EV/cutaneous HPV types 5, 8, 14, 20, 21, 25, and 47 in- duce morphological transformation in 3Y1 cells [118]. The oncogenic potential of HPV types 5, 8, and 47 is higher than those of HPV types 14, 20, 21, and 25. The E7 genes of HPV 8 and HPV 47 fail to induce morphological transformation in rodent fibroblast lines suggesting that E6 rather than E7 is correlated to malignant conversion [116,119]. However, HPV 8 E7 is able to transform rodent cells concertedly with the activated Ha-ras oncogene [120]. The first study analysing the ability of cutaneous HPV types to immortalise human foreskin keratinocytes was performed with HPV 1 and HPV 8 [121]. Furthermore, the E6 or E7 gene of HPV 1, showing a transformed phenotype in rodent cells, is not able to immortalise human keratinocytes, and only a weak immortalising potential for HPV 8 E7 has been observed. The E6/E7 protein of EV/cutaneous HPV 38, but not HPV 10 and HPV 20, displays transforming activity by increasing the life span of human primary keratinocytes [122]. Additionally, HPV 38 E7 is able to degrade and inactivate the tumour suppressor gene $p R b$.

Purdie and colleagues [123] were the first to demonstrate UV-induced activation of the viral promotor of the cutaneous type HPV 77 that was identified in cutaneous lesions from OTR. The promotor contains a p53 binding site, and the response is mediated through the UV-induced expression of $p 53$. The influence of UV-radiation varies on viral gene expression of wartsassociated types (HPV types 1, 2, 3, 7, 27, 41, and 77) and EV/cutaneous types (HPV types 5, 20, 23, and 38) [124]. The presence or absence of wild-type or mutated p53 influences the gene expression of HPV types 20,27, and 77, but not of HPV 41, suggesting that p53 is not an exclusive factor involved in the interaction between UV-radiation and HPV. UV-induced cytokines activate the promotor of HPV 20, but inhibit the promotor of the warts-associated type HPV 27 [125].

Independently from $p 53$ degradation, the E6 protein of HPV 5 inhibits apoptosis in response to UVdamage [126] by inactivation of the pro-apoptotic protein Bak [127]. Moreover, HPV-negative skin cancers express Bak that is in contrast to HPV-positive cancers, in which Bak has not been detected. This underscores the importance and clinical relevance of the interaction between the UV-induced Bak protein and EV/cutaneous HPV types. E6 of both HPV 1 and HPV 8 binds $X R C C 1$, a protein that is required for DNA repair suggesting a link between EV/cutaneous HPV and the according host pathways [128]. The E6 protein of HPV 5 compromises the repair of UV-induced thymine dimers [129], and E6 of HPV 77 additional- 
ly forces keratinocytes into the S1-phase by inhibiting p53-activated, pro-apoptotic genes [130]. However, the E6 expression of beta-HPV 5 does not interfere with such pro-apoptotic genes indicating that this is probably not the favoured mechanism of EV/cutaneous HPV types in the cell. The anti-apoptotic activity, and the delay of the DNA-repair mechanism, may lead to the persistence of UV-damaged keratinocytes suggesting that cutaneous/EV HPV may be involved in the early stages of skin carcinogenesis.

\subsubsection{Organotypic keratinocytes cultures}

Functional analyses of EV/cutaneous HPV types have been retarded for a long time because of both the relation between viral development and host cell differentiation, in addition to the lack of a system with continuously differentiating keratinocytes that constitute a stratified epithelium (i.e., the natural target cells of PV). However, the organotypic raft culture partly has such properties and consists of human primary keratinocytes, which stratify and differentiate into a squamous epithelium [131]. Growth and differentiation markers are expressed similarly to the human epithelium making this system a key technology for the investigation of human skin carcinogenesis. The E6/E7 genes of the EV/cutaneous HPV types 5, 12, 15, 17, 20 , and 38 have strong effects on the growth and differentiation in organotypic cultures of human primary keratinocytes, but an invasive phenotype have not been observed [132]. HPV 8 E7 promotes invasion of keratinocytes into the dermis [133]. This immortal phenotype was associated with the disruption of the basement membrane and the overexpression of metalloproteinases $M M P-1, M M P-8$, and $M T-1-M M P$.

\subsection{Animal models}

\subsubsection{Cattle and horses}

Using animal models, the role of PV in skin carcinogenesis has been studied at three different levels, namely in naturally occurring lesions, in colonies of animals that have been collected from the field, and in transgenic animals. Most non-human PV have been isolated and sequenced from severe epithelial diseases of warmblooded vertebrates including many gregarious animals such as cattle, dog, and rabbit. Bovine papillomavirus type 4 (BPV 4) from the xi-PV is the etiological agent of epithelial papilloma of the upper alimentary canal in cattle [134]. Carcinoma shows characteristic morphological features with papilloma, which can progress into cancer. However, BPV 4 DNA is found in early pa- pilloma of the alimentary tract, but not in advanced papilloma, oesophageal carcinoma, or adenoma and adenocarcinoma of the lower intestine $[135,136]$. Therefore, the presence of BPV 4 is restricted to the early transformation stages during carcinogenesis ('hit-andrun mechanism'). Decrease of virus load has also been shown in a study investigating AK through SCC developmental stages of human cancers [95]. Thus, the multiple factors including BPV 4 infection that concertedly lead to carcinoma in cattle [137] may serve as animal model for an improved knowledge about the complex role of HPV in human skin cancer.

BPV 1 and BPV 2 belong to the delta-PV exhibiting an E5 open reading frame (ORF), which may have been independently developed from that of the alphaPV [53]. The virus is able to infect horses and play an important role in the development of equine sarcoids [138-140]. Roughly half of the healthy horses having contact with infected fellows carry BPV 1 in their skin [141]. This indicates that the usually strict specificity of PV to their hosts [142] is occasionally dismantled and that interspecies transmission may rarely occur in PV (although without replicative establishment of the virus). However, the underlying mechanisms and the possible impact on the malignant developments of novel host invasion have not been seriously addressed for PV to date [52]. On the contrary, their presence in humans has exclusively been regarded as old primate inheritance [142].

\subsubsection{Cottontail rabbit}

Anatomical sites, in which PV cannot complete the productive life cycle, appear particularly involved in the development of skin cancers. This has also been suggested for malignancies caused by cottontail rabbit PV (CRPV) [46] from the kappa-PV. Viral DNA easily induces papillomata making the cottontail rabbit model a powerful system, which identifies the molecular mechanisms that are required for the induction and progression of epithelial neoplasia. Benign papillomata are induced in nearly all rabbits that are infected by CRPV, and $80 \%$ of the initially benign epithelial tumours progress into carcinoma within 6 to 14 months [143]. The virus thus plays an active role during skin carcinogenesis of domestic rabbits interacting with chemical carcinogens [144]. Mutation analysis of viral DNA shows that only the E7 gene, but not the E4 gene, is involved in the development of papilloma [145]. However, the E4 gene remains an important factor for viral DNA amplification and expression of the late structural proteins [46]. Mutation of the highly conserved amino acids results in replication-competent but transactivation-deficient E2 proteins [146]. 


\subsubsection{Multimammate mouse}

A colony of Mastomys coucha (Smith, 1834) [initially determined as M. natalensis (Smith, 1834)] has been established from animals collected in South Africa, which spontaneously develop multiple benign skin tumours such as papilloma and keratoacanthoma during aging. The animals are latently infected by the first Mastomys natalensis papillomavirus (MnPV 1) [147], which is the etiological agent of the lesions [148-150]. MnPV 1 belongs to the iota-PV and does not contain any E5 ORF. Analogously to HPV 8-induced NMSC in EV patients, MnPV 1 DNA persists episomally, without any evidence of integration [147]. Virus-induced tumours do not regress, but proceed after topical application of carcinogens and tumour promotors of cutaneous SCC [151], which is in contrast to the human keratoacanthoma development. MnPV 1 has a broader tissue specificity than other PV investigated so far, and viral persistence and viral load has been correlated with the development of skin tumors [152]. Thus, Mastomys coucha is an excellent animal model for the study of naturally PV-induced skin carcinogenesis.

\subsubsection{Transgenic mice}

HPV 1 causes hyperproliferation and alterations of skin differentiation in a transgenic mouse model examining benign warts of the animals [153]. The expression of the early genomic region, under the control of the keratin- 6 promotor, shows a similar phenotype like human virus-induced warts. Pfister and colleagues have established the first transgenic mouse model for studies on beta-HPV types using the complete early region of HPV 8 under the control of the keratin-14 promotor [154]. The mice have spontaneously developed cutaneous SCC without additional carcinogens, and benign skin tumours have been observed in $91 \%$ of the animals. The same research group has generated HPV 8-transgenic mice that affect exclusively the gene(s) E2, E6, E7, or E6/E7. Spontaneously developed skin tumours have been observed in E2-, E6-, and E6/E7transgenic mice, whereas the exclusive expression of HPV 8 E7 is not sufficient to induce tumour growth (H. Pfister, personal communication). Tommasino and co-workers [155] have established transgenic mice expressing E6/E7 of HPV 38 under the control of the human keratin-10 promoter. The animals have developed skin tumours after a two-stage carcinogen treatment. Cellular proliferation, hyperplasia, and dysplasia in the epidermis have been spontaneously induced by HPV 38 E6/E7. Transforming properties of HPV 8 and HPV 38 have been thus shown in the system of a transgenic mice model.

\section{Conclusions}

The skin of most humans is infected with an individual spectrum of different cutaneous HPV types, and hair follicles are probably their reservoir. During hostlinked evolution, cutaneous HPV types may have established different ecological niches in human skin tissues including a mutualistic cooperation between HPV and their host cells. Specific triggers such as UV-induced DNA-damage in sun-exposed cells, immunosuppression (e.g., locally UV-induced, systemically in OTR), and/or inactivation of host controlled viral life cycle (e.g., in EV patients) lead to increased HPV replication and subsequently to a higher virus load within the cells. The anti-apoptotic effect of cutaneous HPV types in UV-damaged keratinocytes probably results in persistent viral infections and hence the accumulation of further DNA mutations, putatively leading to immortalised cells (Fig. 2). Thus, cutaneous HPV types seem to be involved as a co-factor in the early onset of cutaneous SCC.

\section{Acknowledgements}

Our research program is supported by funding from the University Hospital Charité, the Dr. Mildred Scheel Stiftung für Krebsforschung/Deutsche Krebshilfe (grant number 70-2588), the European Community (contract number QLK2-CT-2002-01179), and the Roche Organ Transplantation Research Foundation in Switzerland (grant number 590944305). We acknowledge the native speaker M. Patel for reading the manuscript.

\section{References}

[1] R. Marks, G. Rennie and T. Selwood, Malignant transformation of solar keratoses to squamous cell carcinoma, Lancet 1 (1988), 795-797.

[2] T. Johnson, D. Rowe, B. Nelson and N. Swanson, Squamous cell carcinoma of the skin (excluding lip and oral mucosa), $J$ Am Acad Dermatol 26 (1992), 467-484.

[3] C. Cockerell, Histopathology of incipient intraepidermal squamous cell carcinoma ("actinic keratosis"), J Am Acad Dermatol 42 (2000), 11-17.

[4] S. Euvrard, J. Kanitakis and A. Claudy, Skin cancers after organ transplantation, N Engl J Med 348 (2003), 1681-1691.

[5] W. Fu and C. Cockerell, The actinic (solar) keratosis: a 21stcentury perspective, Arch Dermatol 139 (2003), 66-70.

[6] S. Miller, Biology of basal cell carcinoma (Part I), J Am Acad Dermatol 24 (1991), 1-13. 
[7] G. Bowden, Prevention of non-melanoma skin cancer by targeting ultraviolet-B-light signalling, Nat Rev Cancer 4 (2004), 23-35.

[8] D. Slaughter, H. Southwick and W. Smejkal, Field cancerization in oral stratified squamous epithelium; clinical implications of multicentric origin, Cancer 6 (1953), 963-968.

[9] D. Miller and M. Weinstock, Nonmelanoma skin cancer in the United States: incidence, J Am Acad Dermatol 30 (1994), 774-778.

[10] H. Gloster and D. Brodland, The epidemiology of skin cancer, Dermatol Surg 22 (1996), 217-226.

[11] R. DePinho, The age of cancer, Nature 408 (2000), 248-254.

[12] T. Diepgen and V. Mahler, The epidemiology of skin cancer, Br J Dermatol 146 (Suppl 61) (2002), 1-6.

[13] B. Armstrong and A. Kricker, The epidemiology of UV induced skin cancer, J Photochem Photobiol B63 (2001), 8-18.

[14] M. Staples, M. Elwood, R. Burton, J. Williams, R. Marks and G. Giles, Non-melanoma skin cancer in Australia: the 2002 national survey and trends since 1985, Med J Aust 184 (2006), 6-10.

[15] S. Salasche, Epidemiology of actinic keratoses and squamous cell carcinoma, J Am Acad Dermatol 42 (2000), 4-7.

[16] E. Stockfleth, C. Ulrich, T. Meyer, R. Arndt and E. Christophers, Skin diseases following organ transplantation-risk factors and new therapeutic approaches, Transplant Proc $\mathbf{3 3}$ (2001), 1848-1853.

[17] P. Boukamp, Non-melanoma skin cancer: what drives tumor development and progression? Carcinogenesis 26 (2005), 1657-1667.

[18] P. Erb, J. Ji, M. Wernli, E. Kump, A. Glaser and S. Büchner, Role of apoptosis in basal cell and squamous cell carcinoma formation, Immunol Lett 100 (2005), 68-72.

[19] M. Kripke, Ultraviolet radiation and immunology: something new under the sun-presidential address, Cancer Res $\mathbf{5 4}$ (1994), 6102-6105.

[20] M. Kripke and M. Fisher, Immunologic parameters of ultraviolet carcinogenesis, J Natl Cancer Inst 57 (1976), 211215.

[21] D. Brash, A. Ziegler, A. Jonason, J. Simon, S. Kunala and D. Leffell, Sunlight and sunburn in human skin cancer: p53, apoptosis, and tumor promotion, J Investig Dermatol Symp Proc 1 (1996), 136-142.

[22] D. Jih, S. Lyle, R. Elenitsas, D. Elder and G. Cotsarelis, Cytokeratin 15 expression in trichoepitheliomas and a subset of basal cell carcinomas suggests they originate from hair follicle stem cells, J Cutan Pathol 26 (1999), 113-118.

[23] R. Gorlin, Nevoid basal-cell carcinoma syndrome, Medicine (Baltimore) 66 (1987), 98-113.

[24] S. Shanley, J. Ratcliffe, A. Hockey, E. Haan, C. Oley, D. Ravine, N. Martin, C. Wicking and G. Chenevix-Trench, Nevoid basal cell carcinoma syndrome: review of 118 affected individuals, Am J Med Genet 50 (1994), 282-290.

[25] V. Kimonis, A. Goldstein, B. Pastakia, M. Yang, R. Kase, J. DiGiovanna, A. Bale and S. Bale, Clinical manifestations in 105 persons with nevoid basal cell carcinoma syndrome, Am J Med Genet 69 (1997), 299-308.

[26] R. Johnson, A. Rothman, J. Xie, L. Goodrich, J. Bare, J. Bonifas, A. Quinn, R. Myers, D. Cox, E. Epstein Jr. and M. Scott, Human homolog of patched, a candidate gene for the basal cell nevus syndrome, Science 272 (1996), 1668-1671.

[27] H. Hahn, C. Wicking, P. Zaphiropoulous, M. Gailani, S. Shanley, A. Chidambaram, I. Vorechovsky, E. Holmberg, A. Unden, S. Gillies, K. Negus, I. Smyth, C. Pressman, D. Leffell, B. Gerrard, A. Goldstein, M. Dean, R. Toftgard, G.
Chenevix-Trench, B. Wainwright and A. Bale, Mutations of the human homolog of Drosophila patched in the nevoid basal cell carcinoma syndrome, Cell 85 (1996), 841-851.

[28] A. Chidambaram, A. Goldstein, M. Gailani, B. Gerrard, S. Bale, J. DiGiovanna, A. Bale and M. Dean, Mutations in the human homologue of the Drosophila patched gene in Caucasian and African-American nevoid basal cell carcinoma syndrome patients, Cancer Res 56 (1996), 4599-4601.

[29] M. Alam and D. Ratner, Cutaneous squamous-cell carcinoma, N Engl J Med 344 (2001), 975-983.

[30] A. Quinn, S. Sikkink and J. Rees, Delineation of two distinct deleted regions on chromosome 9 in human non-melanoma skin cancers, Genes Chromosomes, Cancer 11 (1994), 222225.

[31] I. Rehman, M. Takata, Y. Wu and J. Rees, Genetic change in actinic keratoses, Oncogene 12 (1996), 2483-2490.

[32] I. Nindl, C. Dang, T. Forschner, R. Kuban, T. Meyer, W. Sterry and E. Stockfleth, Identification of differentially expressed genes in cutaneous squamous cell carcinoma by microarray expression profiling, Mol Cancer 5 (2006), 30

[33] J. Newton, R. Camplejohn and D. McGibbon, A flow cytometric study of the significance of DNA aneuploidy in cutaneous lesions, Br J Dermatol 117 (1987), 169-174.

[34] A. Herzberg, B. Kerns, F. Honkanen, J. Pence, J. Iglehart and R. Kinney, DNA ploidy and proliferation index of soft tissue sarcomas determined by image cytometry of fresh frozen tissue, Am J Clin Pathol 97 (1992), S29-S37.

[35] N. Dumaz, A. Stary, T. Soussi, L. Daya-Grosjean and A. Sarasin, Can we predict solar ultraviolet radiation as the causal event in human tumours by analysing the mutation spectra of the p53 gene? Mutat Res 307 (1994), 375-386.

[36] A. Ziegler, A. Jonason, D. Leffell, J. Simon, H. Sharma, J. Kimmelman, L. Remington, T. Jacks and D. Brash, Sunburn and p53 in the onset of skin cancer, Nature 372 (1994), 773776.

[37] N. Soufir, J. Moles, C. Vilmer, C. Moch, O. Verola, J. Rivet, A. Tesniere, L. Dubertret and N. Basset-Seguin, P16 UV mutations in human skin epithelial tumors, Oncogene 18 (1999), 5477-5481.

[38] V. Brown, C. Harwood, T. Crook, J. Cronin, D. Kelsell and C. Proby, $\mathrm{p} 16^{\mathrm{INK} 4 \mathrm{a}}$ and $\mathrm{p} 14^{\mathrm{ARF}}$ Tumor suppressor genes are commonly inactivated in cutaneous squamous cell carcinoma, J Invest Dermatol 122 (2004), 1284-1292.

[39] H. Kreimer-Erlacher, H. Seidl, B. Bäck, L. Cerroni, H. Kerl and P. Wolf, High frequency of ultraviolet mutations at the INK4a-ARF locus in squamous cell carcinomas from psoralen-plus-ultraviolet-A-treated psoriasis patients, J Invest Dermatol 120 (2003), 676-682.

[40] Z. Saridaki, T. Liloglou, A. Zafiropoulos, E. Koumantaki, O. Zoras and D. Spandidos, Mutational analysis of CDKN2A genes in patients with squamous cell carcinoma of the skin, Br J Dermatol 148 (2003), 638-648.

[41] H. Ananthaswamy and W. Pierceall, Molecular alterations in human skin tumors, Prog Clin Biol Res 376 (1992), 61-84.

[42] S. Popp, S. Waltering, C. Herbst, I. Moll and P. Boukamp, UV-B-type mutations and chromosomal imbalances indicate common pathways for the development of Merkel and skin squamous cell carcinomas, Int J Cancer 99 (2002), 352-360.

[43] A. Jonason, S. Kunala, G. Price, R. Restifo, H. Spinelli, J. Persing, D. Leffell, R. Tarone and D. Brash, Frequent clones of p53-mutated keratinocytes in normal human skin, Proc Natl Acad Sci USA 93 (1996), 14025-14029.

[44] F. Moloney, H. Comber, P. O'Lorcain, P. O'Kelly, P. Conlon and G. Murphy, A population-based study of skin cancer 
incidence and prevalence in renal transplant recipients, $\mathrm{BrJ}$ Dermatol 154 (2006), 498-504.

[45] B. Akgül, J. Cooke and A. Storey, HPV-associated skin disease, J. Pathol 208 (2006), 165-175.

[46] J. Doorbar, The papillomavirus life cycle, J Clin Virol 32 (2005), 7-15

[47] E.-M. de Villiers, C. Fauquet, T. Broker, H.-U. Bernard and H. zur Hausen, Classification of papillomaviruses, Virology 324 (2004), 17-27.

[48] International Agency for Research on Cancer, IARC monographs on the evaluation of carcinogenic risks to humans. Human papillomaviruses, IARC Lyon France 64 (1995).

[49] N. Muñoz, F. Bosch, S. de Sanjose, R. Herrero, X. Castellsague, K. Shah, P. Snijders and C. Meijer, Epidemiologic classification of human papillomavirus types associated with cervical cancer, N Engl J Med 348 (2003), 518-527.

[50] A. Narechania, Z. Chen, R. DeSalle and R. Burk, Phylogenetic incongruence among oncogenic genital alpha human papillomaviruses, J Virol 79 (2005), 15503-15510.

[51] H. zur Hausen, Papillomaviruses and cancer: From basic studies to clinical application, Nat Rev Cancer 2 (2002), 342-350.

[52] M. Gottschling, A. Köhler, E. Stockfleth and I. Nindl, Phylogenetic analysis of beta-papillomaviruses as inferred from nucleotide and amino acid sequence data, Mol Phylogenet Evol 42 (2007), 213-222.

[53] I. Bravo and A. Alonso, Mucosal human papillomaviruses encode four different E5 proteins whose chemistry and phylogeny correlate with malignant or benign growth, $J$ Virol 78 (2004), 13613-13626.

[54] S. Garcia-Vallve, A. Alonso and I. Bravo, Papillomaviruses: different genes have different histories, Trends Microbiol 13 (2005), 514-521.

[55] F. Lewandowsky and W. Lutz, Ein Fall einer bisher nicht beschriebenen Hauterkrankung (Epidermodysplasia verruciformis), Arch Dermatol Syphilol 141 (1922), 193-203.

[56] S. Jablonska, J. Dabrowski and K. Jakubowicz, Epidermodysplasia verruciformis as a model in studies on the role of papovaviruses in oncogenesis, Cancer Res 32 (1972), 583589.

[57] G. Orth, S. Jablonska, M. Favre, O. Croissant, M. JarzabekChorzelska and G. Rzesa, Characterization of two types of human papillomaviruses in lesions of Epidermodysplasia verruciformis, Proc Natl Acad Sci USA 75 (1978), 15371541.

[58] S. Majewski and S. Jablonska, Human papillomavirusassociated tumors of the skin and mucosa, J Am Acad Dermatol 36 (1997), 659-685.

[59] M. Favre, N. Ramoz and G. Orth, Human papillomaviruses: General features, Clin Dermatol 15 (1997), 181-198.

[60] N. Wentzensen, R. Ridder, R. Kläs, S. Vinokurova, U. Schäfer and M. Doeberitz, Characterization of viral-cellular fusion transcripts in a large series of HPV16 and 18 positive anogenital lesions, Oncogene 21 (2002), 419-426.

[61] H. Pfister, Chapter 8: Human papillomavirus and skin cancer, J Natl Cancer Inst Monogr (2003), 52-56.

[62] M. Yutsudo and A. Hakura, Human papillomavirus type 17 transcripts expressed in skin carcinoma tissue of a patient with Epidermodysplasia verruciformis, Int J Cancer 39 (1987), 586-589.

[63] K. Haller, F. Stubenrauch and H. Pfister, Differentiation-dependent transcription of the Epidermodysplasia verruciformis-associated human papillomavirus type 5 in benign lesions, Virology 214 (1995), 245-255.
[64] R. Ostrow, M. Bender, M. Niimura, T. Seki, M. Kawashima, F. Pass and A. Faras, Human papillomavirus DNA in cutaneous primary and metastasized squamous cell carcinomas from patients with Epidermodysplasia verruciformis, Proc Natl Acad Sci USA 79 (1982), 1634-1638.

[65] H. Pfister and J. Ter Schegget, Role of HPV in cutaneous premalignant and malignant tumors, Clin Dermatol 15 (1997), 335-347.

[66] S. Majewski and S. Jablonska, Do Epidermodysplasia verruciformis human papillomaviruses contribute to malignant and benign epidermal proliferations? Arch Dermatol 138 (2002), 649-654.

[67] N. Ramoz, L. Rueda, B. Bouadjar, L. Montoya, G. Orth and M. Favre, Mutations in two adjacent novel genes are associated with Epidermodysplasia verruciformis, Nat Genet 32 (2002), 579-581.

[68] N. Ramoz, L. Rueda, B. Bouadjar, M. Favre and G. Orth, A susceptibility locus for Epidermodysplasia verruciformis, an abnormal predisposition to infection with the oncogenic human papillomavirus type 5 , maps to chromosome 17 qter in a region containing a psoriasis locus, $J$ Invest Dermatol 112 (1999), 259-263.

[69] N. Ramoz, A. Taieb, L. Rueda, L. Montoya, B. Bouadjar, M. Favre and G. Orth, Evidence for a nonallelic heterogeneity of Epidermodysplasia verruciformis with two susceptibility loci mapped to chromosome regions 2p21-p24 and 17q25, $J$ Invest Dermatol 114 (2000), 1148-1153.

[70] G. Keresztes, H. Mutai and S. Heller, TMC and EVER genes belong to a larger novel family, the $T M C$ gene family encoding transmembrane proteins, BMC Genomics 4 (2003), 24.

[71] K. Kurima, Y. Yang, K. Sorber and A. Griffith, Characterization of the transmembrane channel-like (TMC) gene family: functional clues from hearing loss and Epidermodysplasia verruciformis, Genomics 82 (2003), 300-308.

[72] A. Antonsson, S. Karanfilovska, P. Lindqvist and B. Hansson, General acquisition of human papillomavirus infections of skin occurs in early infancy, J Clin Microbiol 41 (2003), 2509-2514.

[73] I. Boxman, R. Berkhout, L. Mulder, M. Wolkers, J. Bouwes Bavinck, B. Vermeer and J. Ter Schegget, Detection of human papillomavirus DNA in plucked hairs from renal transplant recipients and healthy volunteers, J Invest Dermatol 108 (1997), 712-715.

[74] I. Boxman, L. Mulder, A. Russell, J. Bouwes Bavinck, A. Green and J. Ter Schegget, Human papillomavirus type 5 is commonly present in immunosuppressed and immunocompetent individuals, Br J Dermatol 141 (1999), 246-249.

[75] I. Boxman, A. Russell, L. Mulder, J. Bouwes Bavinck, J. Ter Schegget, A. Green and Collaborators of the Nambour Prevention Study, Case-control study in a subtropical Australian population to assess the relation between non-melanoma skin cancer and Epidermodysplasia verruciformis human papillomavirus DNA in plucked eyebrow hairs, Int J Cancer 86 (2000), 118-121.

[76] A. Köhler, T. Forschner, T. Meyer, C. Ulrich, M. Gottschling, E. Stockfleth and I. Nindl, Multifocal distribution of cutaneous human papillomavirus types in hairs from different skin areas, Br. J. Dermatol (in press).

[77] L. Tieben, J. Ter Schegget, R. Minnaar, J. Bouwes Bavinck, R. Berkhout, B. Vermeer, M. Jebbink and H. Smits, Detection of cutaneous and genital HPV types in clinical samples by PCR using consensus primers, J Virol Methods 42 (1993), 265-279. 
[78] V. Shamanin, H. Delius and E.M. de Villiers, Development of a broad spectrum PCR assay for papillomaviruses and its application in screening lung cancer biopsies, J Gen Virol 75 (1994), 1149-1156.

[79] R. Berkhout, L. Tieben, H. Smits, J. Bouwes Bavinck, B. Vermeer and J. Ter Schegget, Nested PCR approach for detection and typing of Epidermodysplasia verruciformis-associated human papillomavirus types in cutaneous cancers from renal transplant recipients, J Clin Microbiol 33 (1995), 690-695.

[80] C. Harwood, P. Spink, T. Surentheran, I. Leigh, E.-M. de Villiers, J. McGregor, C. Proby and J. Breuer, Degenerate and nested PCR: A highly sensitive and specific method for detection of human papillomavirus infection in cutaneous warts, J Clin Microbiol 37 (1999), 3545-3555.

[81] O. Forslund, A. Antonsson, P. Nordin, B. Stenquist and B. Hansson, A broad range of human papillomavirus types detected with a general PCR method suitable for analysis of cutaneous tumours and normal skin, J Gen Virol 80 (1999), 2437-2443.

[82] T. Meyer, R. Arndt, E. Christophers and E. Stockfleth, Frequency and spectrum of HPV types detected in cutaneous squamous-cell carcinomas depend on the HPV detection system: A comparison of four PCR assays, Dermatology 201 (2000), 204-211.

[83] D. O'Connor, E. Kay, M. Leader, G. Murphy, G. Atkins, and M. Mabruk, Altered $p 53$ expression in benign and malignant skin lesions from renal transplant recipients and immunocompetent patients with skin cancer: Correlation with human papillomaviruses? Diagn Mol Pathol 10 (2001), 190-199.

[84] A. Brink, B. Lloveras, I. Nindl, D. Heideman, D. Kramer, R. Pol, M. Fuente, C. Meijer and P. Snijders, Development of a general-primer-PCR-reverse-line-blotting system for detection of beta and gamma cutaneous human papillomaviruses, J Clin Microbiol 43 (2005), 5581-5587.

[85] M. de Koning, W. Quint, L. Struijk, B. Kleter, P. Wanningen, L. van Doorn, S. Weissenborn, M. Feltkamp and J. Ter Schegget, Evaluation of a novel highly sensitive, broadspectrum PCR-reverse hybridization assay for detection and identification of beta-papillomavirus DNA, J Clin Microbiol 44 (2006), 1792-1800.

[86] G. Astori, D. Lavergne, C. Benton, B. Hockmayr, K. Egawa, C. Garbe and E. de Villiers, Human papillomaviruses are commonly found in normal skin of immunocompetent hosts, J Invest Dermatol 110 (1998), 752-755.

[87] C. Harwood, T. Surentheran, J. McGregor, P. Spink, I. Leigh, J. Breuer and C. Proby, Human papillomavirus infection and non-melanoma skin cancer in immunosuppressed and immunocompetent individuals, J Med Virol 61 (2000), 289297.

[88] T. Meyer, R. Arndt, E. Christophers, I. Nindl and E. Stockfleth, Importance of human papillomaviruses for the development of skin cancer, Cancer Detect Prev 25 (2001), 533547.

[89] O. Forslund, H. Ly, C. Reid and G. Higgins, A broad spectrum of human papillomavirus types is present in the skin of Australian patients with non-melanoma skin cancers and solar keratosis, Br J Dermatol 149 (2003), 64-73.

[90] H. Pfister, P. Fuchs, S. Majewski, S. Jablonska, I. Pniewska and M. Malejczyk, High prevalence of Epidermodysplasia verruciformis-associated human papillomavirus DNA in actinic keratoses of the immunocompetent population, Arch Dermatol Res 295 (2003), 273-279.

[91] U. Wieland, A. Ritzkowsky, M. Stoltidis, S. Weissenborn, S. Stark, M. Ploner, S. Majewski, S. Jablonska, H. Pfister and P. Fuchs, Papillomavirus DNA in basal cell carcinomas of immunocompetent patients: an accidental association? $J$ Invest Dermatol 115 (2000), 124-128.

[92] D. O'Connor, E. Kay, M. Leader, G. Atkins, G. Murphy and M. Mabruk, p53 codon 72 polymorphism and human papillomavirus associated skin cancer, J Clin Pathol 54 (2001), 539-542.

[93] O. Forslund, A. Antonsson, G. Higgins, H. Ly, H. Delius, A. Hunziker and E.-M. de Villiers, Nucleotide sequence and phylogenetic classification of candidate human papilloma virus type 92, Virology 312 (2003), 255-260.

[94] I. Nindl, A. Köhler, T. Meyer, T. Forschner, C. Meijer, P. Snijders, W. Sterry and E. Stockfleth, Detection of human papillomavirus DNA in primary squamous cell carcinoma and metastases, Br J Dermatol 154 (2006), 797-799.

[95] S. Weissenborn, I. Nindl, K. Purdie, C. Harwood, C. Proby, J. Breuer, S. Majewski, H. Pfister and U. Wieland, Human papillomavirus-DNA loads in actinic keratoses exceed those in non-melanoma skin cancers, J Invest Dermatol 125 (2005), 93-97.

[96] L. Struijk, J. Bouwes Bavinck, P. Wanningen, E. van der Meijden, R. Westendorp, J. Ter Schegget and M. Feltkamp, Presence of human papillomavirus DNA in plucked eyebrow hairs is associated with a history of cutaneous squamous cell carcinoma, J Invest Dermatol 121 (2003), 1531-1535.

[97] J. Bouwes Bavinck, S. Stark, A. Petridis, M. Marugg, J. Ter Schegget, R. Westendorp, P. Fuchs, B. Vermeer and H. Pfister, The presence of antibodies against virus-like particles of Epidermodysplasia verruciformis-associated humanpapillomavirus type 8 in patients with actinic keratoses, $\mathrm{Br} \mathrm{J}$ Dermatol 142 (2000), 103-109.

[98] C. Masini, P. Fuchs, F. Gabrielli, S. Stark, F. Sera, M. Ploner, C. Melchi, G. Primavera, G. Pirchio, O. Picconi, P. Petasecca, M. Cattaruzza, H. Pfister and D. Abeni, Evidence for the association of human papillomavirus infection and cutaneous squamous cell carcinoma in immunocompetent individuals, Arch Dermatol 139 (2003), 890-894.

[99] S. Stark, A. Petridis, S. Ghim, A. Jenson, J. Bouwes Bavinck, G. Gross, E. Stockfleth, P. Fuchs and H. Pfister, Prevalence of antibodies against virus-like particles of Epidermodysplasia verruciformis-associated HPV8 in patients at risk of skin cancer, J Invest Dermatol 111 (1998), 696-701.

[100] M. Feltkamp, R. Broer, F. di Summa, L. Struijk, Meijden van der, B. Verlaan, R. Westendorp, J. Ter Schegget, W. Spaan and J. Bouwes Bavinck, Seroreactivity to Epidermodysplasia verruciformis-related human papillomavirus types is associated with nonmelanoma skin cancer, Cancer Res 63 (2003), 2695-2700.

[101] M. Karagas, H. Nelson, P. Sehr, T. Waterboer, T. Stukel, A. Andrew, A. Green, J. Bouwes Bavinck, A. Perry, S. Spencer, J. Rees, L. Mott and M. Pawlita, Human papillomavirus infection and incidence of squamous cell and basal cell carcinomas of the skin, J Natl Cancer Inst 98 (2006), 389-395.

[102] J. Boyle, R. Mackie, J. Briggs, B. Junor and T. Aitchison, Cancer, warts, and sunshine in renal transplant patients. A case-control study, Lancet 1 (1984), 702-705.

[103] J. Bouwes Bavinck, B. Vermeer, F. Van der Woude, J. Vandenbroucke, G. Schreuder, J. Thorogood, G. Persijn and F. Claas, Relation between skin cancer and HLA antigens in renal-transplant recipients, N Engl J Med 325 (1991), 843848.

[104] S. Birkeland, H. Storm, L. Lamm, L. Barlow, I. Blohme, B. Forsberg, B. Eklund, O. Fjeldborg, M. Friedberg and L. 
Frodin, Cancer risk after renal transplantation in the Nordic countries, 1964-1986, Int J Cancer 60 (1995), 183-189.

[105] M. Hartevelt, J. Bouwes Bavinck, A. Kootte, B. Vermeer and J. Vandenbroucke, Incidence of skin cancer after renal transplantation in The Netherlands, Transplantation 49 (1990), 506-509.

[106] J. Bouwes Bavinck, D. Hardie, A. Green, S. Cutmore, A. MacNaught, B. O’Sullivan, V. Siskind, F. Van der Woude and I. Hardie, The risk of skin cancer in renal transplant recipients in Queensland, Australia. A follow-up study, Transplantation 61 (1996), 715-721.

[107] K. Blessing, K. McLaren, E. Benton, B. Barr, M. Bunney, I. Smith and G. Beveridge, Histopathology of skin lesions in renal allograft recipients-an assessment of viral features and dysplasia, Histopathology 14 (1989), 129-139.

[108] S. Euvrard, Y. Chardonnet, C. Pouteil Noble, J. Kanitakis, M. Chignol, J. Thivolet and J. Touraine, Association of skin malignancies with various and multiple carcinogenic and noncarcinogenic human papillomaviruses in renal transplant recipients, Cancer 72 (1993), 2198-2206.

[109] V. Shamanin, M. Glover, C. Rausch, C. Proby, I. Leigh, H. zur Hausen and E.-M. de Villiers, Specific types of human papillomavirus found in benign proliferations and carcinomas of the skin in immunosuppressed patients, Cancer Res 54 (1994), 4610-4613.

[110] L. de Jong-Tieben, R. Berkhout, H. Smits, J. Bouwes Bavinck, B. Vermeer, F. Van der Woude and J. Ter Schegget, High frequency of detection of Epidermodysplasia verruciformis-associated human papillomavirus DNA in biopsies from malignant and premalignant skin lesions from renal transplant recipients, J Invest Dermatol 105 (1995), 367-371.

[111] E.-M. de Villiers, D. Lavergne, K. McLaren and E. Benton, Prevailing papillomavirus types in non-melanoma carcinomas of the skin in renal allograft recipients, Int J Cancer $\mathbf{7 3}$ (1997), 356-361.

[112] R. Berkhout, J. Bouwes Bavinck and J. Ter Schegget, Persistence of human papillomavirus DNA in benign and (pre)malignant skin lesions from renal transplant recipients, J Clin Microbiol 38 (2000), 2087-2096.

[113] L. de Jong-Tieben, R. Berkhout, J. Ter Schegget, B. Vermeer, J. de Fijter, J. Bruijn, R. Westendorp and J. Bouwes Bavinck, The prevalence of human papillomavirus DNA in benign keratotic skin lesions of renal transplant recipients with and without a history of skin cancer is equally high: A clinical study to assess risk factors for keratotic skin lesions and skin cancer, Transplantation 69 (2000), 44-49.

[114] K. Purdie, T. Surentheran, J. Sterling, L. Bell, J. McGregor, C. Proby, C. Harwood and J. Breuer, Human papillomavirus gene expression in cutaneous squamous cell carcinomas from immunosuppressed and immunocompetent individuals, $J$ Invest Dermatol 125 (2005), 98-107.

[115] C. Dang, A. Köhler, T. Forschner, P. Sehr, K. Michael, M. Pawlita, E. Stockfleth and I. Nindl, E6/E7 expression of human papillomavirus types in cutaneous squamous cell dysplasia and carcinoma in immunosuppressed organ transplant recipients, Br J Dermatol 155 (2006), 129-136.

[116] T. Iftner, S. Bierfelder, Z. Csapo and H. Pfister, Involvement of human papillomavirus type 8 genes E6 and E7 in transformation and replication, $J$ Virol 62 (1988), 3655-3661.

[117] T. Kiyono, K. Nagashima and M. Ishibashi, The primary structure of major viral RNA in a rat cell line transfected with type 47 human papillomavirus DNA and the transforming activity of its cDNA and E6 gene, Virology 173 (1989), 551565.

[118] T. Kiyono, A. Hiraiwa and M. Ishibashi, Differences in transforming activity and coded amino acid sequence among E6 genes of several papillomaviruses associated with Epidermodysplasia verruciformis, Virology 186 (1992), 628-639.

[119] A. Hiraiwa, T. Kiyono, K. Segawa, K. Utsumi, M. Ohashi and M. Ishibashi, Comparative study on E6 and E7 genes of some cutaneous and genital papillomaviruses of human origin for their ability to transform 3Y1 cells, Virology 192 (1993), 102-111.

[120] T. Yamashita, K. Segawa, Y. Fujinaga, T. Nishikawa and K. Fujinaga, Biological and biochemical activity of E7 genes of the cutaneous human papillomavirus type 5 and 8 , Oncogene 8 (1993), 2433-2441.

[121] A. Schmitt, J. Harry, B. Rapp, F. Wettstein and T. Iftner, Comparison of the properties of the E6 and E7 genes of low- and high-risk cutaneous papillomaviruses reveals strongly transforming and high $R b$-binding activity for the E7 protein of the low-risk human papillomavirus type 1, J Virol 68 (1994), 7051-7059.

[122] S. Caldeira, I. Zehbe, R. Accardi, I. Malanchi, W. Dong, M. Giarre, E.-M. de Villiers, R. Filotico, P. Boukamp and M. Tommasino, The E6 and E7 proteins of the cutaneous human papillomavirus type 38 display transforming properties, $J$ Virol 77 (2003), 2195-2206.

[123] K. Purdie, J. Pennington, C. Proby, S. Khalaf, E.-M. de Villiers, I. Leigh and A. Storey, The promoter of a novel human papillomavirus (HPV77) associated with skin cancer displays UV responsiveness, which is mediated through a consensus $p 53$ binding sequence, EMBO J 18 (1999), 53595369.

[124] E. de Villiers, A. Ruhland and P. Sekaric, Human papillomaviruses in non-melanoma skin cancer, Semin Cancer Biol 9 (1999), 413-422.

[125] A. Ruhland and E.-M. de Villiers, Opposite regulation of the HPV 20-URR and HPV 27-URR promoters by ultraviolet irradiation and cytokines, Int J Cancer 91 (2001), 828-834.

[126] S. Jackson and A. Storey, E6 proteins from diverse cutaneous HPV types inhibit apoptosis in response to UV damage, Oncogene 19 (2000), 592-598.

[127] S. Jackson, C. Harwood, M. Thomas, L. Banks and A. Storey, Role of Bak in UV-induced apoptosis in skin cancer and abrogation by HPV E6 proteins, Genes Dev 14 (2000), 30653073.

[128] T. Iftner, M. Elbel, B. Schopp, T. Hiller, J. Loizou, K. Caldecott and F. Stubenrauch, Interference of papillomavirus E6 protein with single-strand break repair by interaction with XRCC1, EMBO J 21 (2002), 4741-4748.

[129] S. Giampieri and A. Storey, Repair of UV-induced thymine dimers is compromised in cells expressing the E6 protein from human papillomaviruses types 5 and $18, \mathrm{Br} J$ Cancer 90 (2004), 2203-2209.

[130] S. Giampieri, R. Garcia-Escudero, J. Green and A. Storey, Human papillomavirus type 77 E6 protein selectively inhibits p53-dependent transcription of proapoptotic genes following UV-B irradiation, Oncogene 23 (2004), 5864-5870.

[131] L. Chow and T. Broker, In vitro experimental systems for HPV: Epithelial raft cultures for investigations of viral reproduction and pathogenesis and for genetic analyses of viral proteins and regulatory sequences, Clin Dermatol 15 (1997), 217-227.

[132] I. Boxman, L. Mulder, F. Noya, V de Waard, S. Gibbs, T. Broker, F. ten Kate, L. Chow and J. Ter Schegget, Trans- 
duction of the E6 and E7 genes of Epidermodysplasiaverruciformis-associated human papillomaviruses alters human keratinocyte growth and differentiation in organotypic cultures, J Invest Dermatol 117 (2001), 1397-1404.

[133] B. Akgül, R. Garcia-Escudero, L. Ghali, H. Pfister, P. Fuchs, H. Navsaria and A. Storey, The E7 protein of cutaneous human papillomavirus type 8 causes invasion of human keratinocytes into the dermis in organotypic cultures of skin, Cancer Res 65 (2005), 2216-2223.

[134] M. Campo, M. Moar, W. Jarrett and H. Laird, A new papillomavirus associated with alimentary cancer in cattle, Nature 286 (1980), 180-182.

[135] M. Campo, M. Moar, M. Sartirana, I. Kennedy and W. Jarrett, The presence of bovine papillomavirus type 4 DNA is not required for the progression to, or the maintenance of, the malignant state in cancers of the alimentary canal in cattle, EMBO J 4 (1985), 1819-1825.

[136] M. Campo, B. O’Neil, R. Barron and W. Jarrett, Experimental reproduction of the papilloma-carcinoma complex of the alimentary canal in cattle, Carcinogenesis 15 (1994), 15971601.

[137] M. Jackson, M. Campo and J. Gaukroger, Cooperation between papillomavirus and chemical cofactors in oncogenesis, Crit Rev Oncog 4 (1993), 277-291.

[138] H. Pfister, B. Fink and C. Thomas, Extrachromosomal bovine papillomavirus type 1 DNA in hamster fibromas and fibrosarcomas, Virology 115 (1981), 414-418.

[139] N. Otten, C. von Tscharner, S. Lazary, D. Antczak and H. Gerber, DNA of bovine papillomavirus type 1 and 2 in equine sarcoids: PCR detection and direct sequencing, Arch Virol 132 (1993), 121-131.

[140] G. Chambers, V. Ellsmore, P. O’Brien, S. Reid, S. Love, M. Campo and L. Nasir, Association of bovine papillomavirus with the equine sarcoid, J Gen Virol 84 (2003), 1055-1062.

[141] L. Bogaert, A. Martens, C. De Baere and F. Gasthuys, Detection of bovine papillomavirus DNA on the normal skin and in the habitual surroundings of horses with and without equine sarcoids, Res Vet Sci 79 (2005), 253-258.

[142] H. Bernard, I. Calleja-Macias and S. Dunn, Genome variation of human papillomavirus types: phylogenetic and medical implications, Int J Cancer 118 (2006), 1071-1076.

[143] F. Wettstein, M. Barbosa and M. Nasseri, Identification of the major cottontail rabbit papillomavirus late RNA cap site and mapping and quantitation of an E2 and minor E6 coding mRNA in papillomas and carcinomas, Virology 159 (1987), 321-328.

[144] S. Watts, R. Ostrow, W. Phelps, J. Prince and A. Faras, Free cottontail rabbit papillomavirus DNA persists in warts and carcinomas of infected rabbits and in cells in culture transformed with virus or viral DNA, Virology 125 (1983), 127138.

[145] J. Brandsma, Z. Yang, S. Barthold and E. Johnson, Use of a rapid, efficient inoculation method to induce papillomas by cottontail rabbit papillomavirus DNA shows that the E7 gene is required, Proc Natl Acad Sci USA 88 (1991), 4816-4820.

[146] S. Jeckel, E. Huber, F. Stubenrauch and T. Iftner, A transactivator function of cottontail rabbit papillomavirus E2 is essential for tumor induction in rabbits, J Virol 76 (2002), 11209-11215.

[147] E. Amtmann, M. Volm and K. Wayss, Tumour induction in the rodent Mastomys natalensis by activation of endogenous papilloma virus genomes, Nature 308 (1984), 291-292.

[148] H. Müller and L. Gissmann, Mastomys natalensis papilloma virus (MnPV), the causative agent of epithelial proliferations: characterization of the virus particle, J Gen Virol 41 (1978), 315-323.

[149] R. Rudolph, H. Müller, M. Reinacher and W. Thiel, Morphology of experimentally induced so-called keratoacanthomas and squamous cell carcinomas in 2 inbred-lines of Mastomys natalensis, J Comp Pathol 91 (1981), 123-134.

[150] C. Tan, R. Tachezy, M. Van Ranst, S. Chan, H. Bernard and R. Burk, The Mastomys natalensis papillomavirus: Nucleotide sequence, genome organization, and phylogenetic relationship of a rodent papillomavirus involved in tumorigenesis of cutaneous epithelia, Virology 198 (1994), 534-541.

151] E. Amtmann, M. Volm and K. Wayss, The Mastomys natalensis papillomavirus, in: The Papoviridae, N. Salzmann and P. Howley, eds, Plenum Publishing Corporation, 1987, pp. $187-198$.

[152] J. Nafz, A. Köhler, M. Ohnesorge, I. Nindl, E. Stockfleth and F. Rösl, Presence and distribution of Mastomys natalensis papillomavirus in its natural host, submitted (2007).

[153] J. Tinsley, C. Fisher and P. Searle, Abnormalities of epidermal differentiation associated with expression of the human papillomavirus type 1 early region in transgenic mice, $J$ Gen Virol 73 (1992), 1251-1260.

[154] I. Schaper, G. Marcuzzi, S. Weissenborn, H. Kasper, V. Dries, N. Smyth, P. Fuchs and H. Pfister, Development of skin tumors in mice transgenic for early genes of human papillomavirus type 8, Cancer Res 65 (2005), 1394-1400.

[155] W. Dong, U. Kloz, R. Accardi, S. Caldeira, W. Tong, Z. Wang, L. Jansen, M. Durst, B. Sylla, L. Gissmann and M. Tommasino, Skin hyperproliferation and susceptibility to chemical carcinogenesis in transgenic mice expressing E6 and E7 of human papillomavirus type 38, J Virol 79 (2005), 14899-14908. 


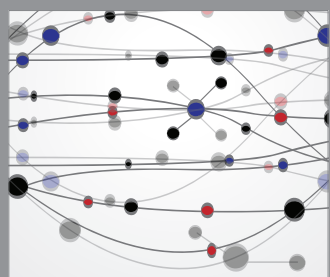

The Scientific World Journal
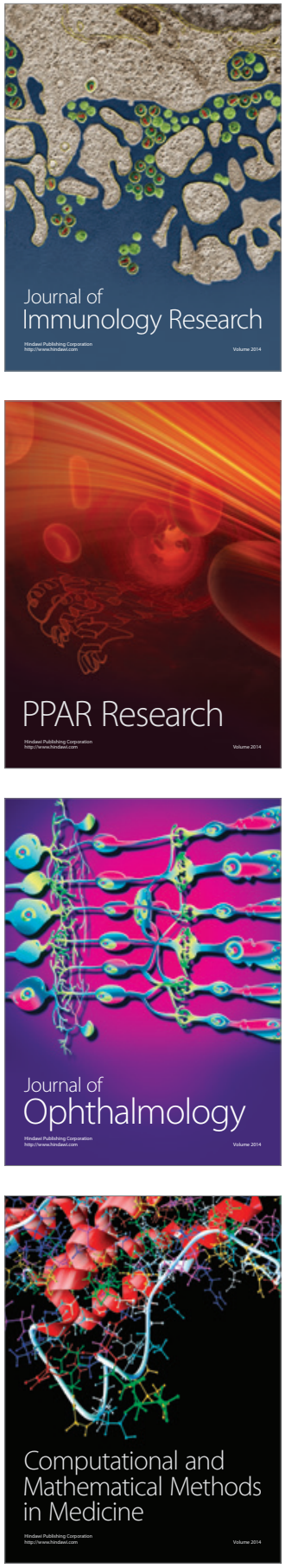

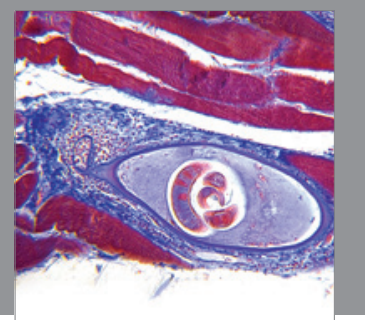

Gastroenterology

Research and Practice
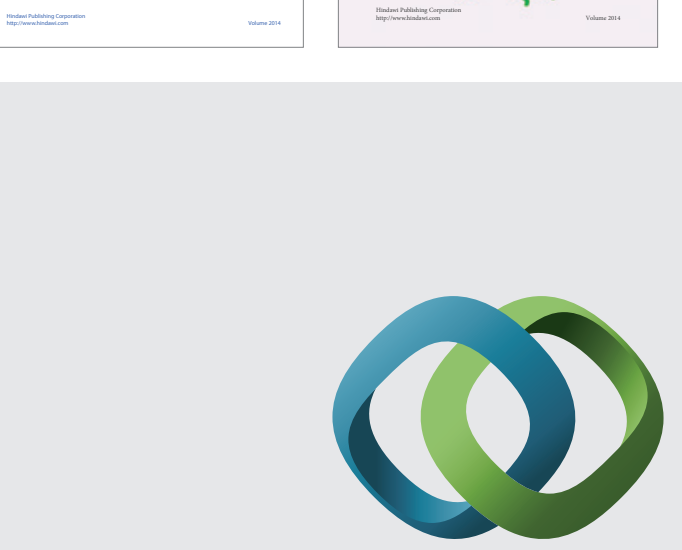

\section{Hindawi}

Submit your manuscripts at

http://www.hindawi.com
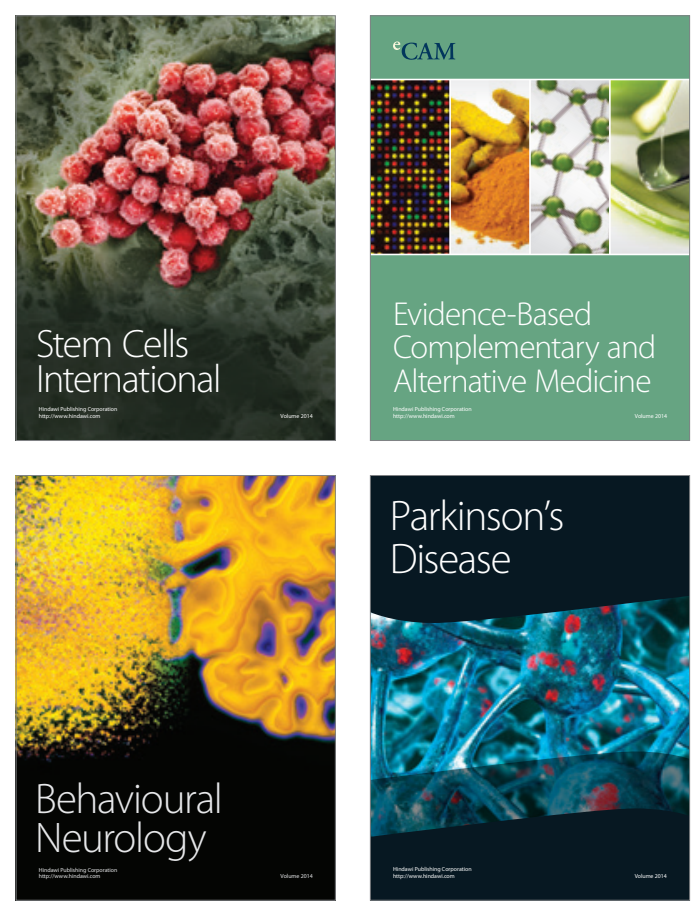

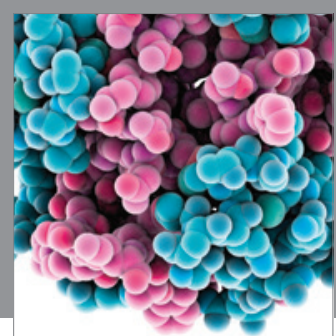

Journal of
Diabetes Research

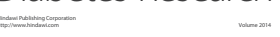

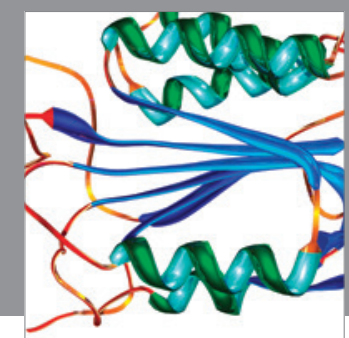

Disease Markers
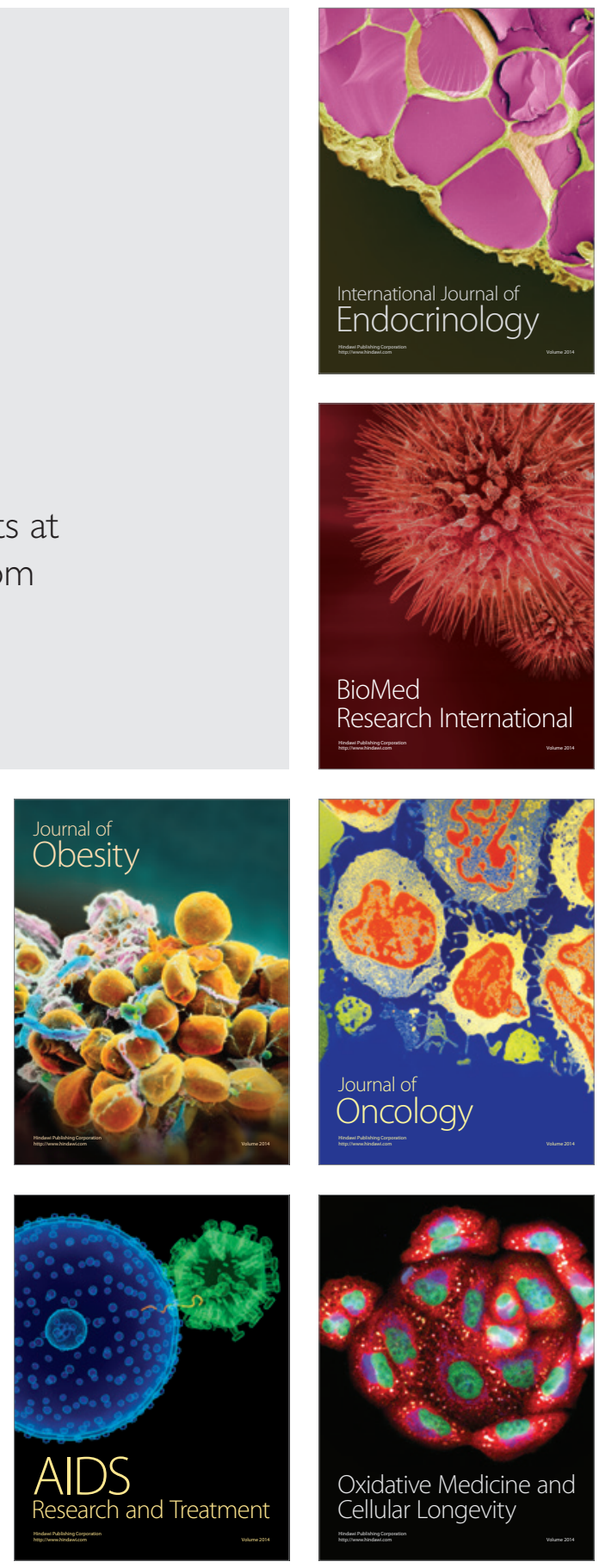